\title{
A New Sensitive Spectrophotometric Determination of Cypermethrin Insecticide in Environmental and Biological Samples
}

\author{
E. K. Janghel, ${ }^{*, a}$ J. K. Rai, ${ }^{a}$ M. K. Rai ${ }^{b}$ and V. K. Gupta ${ }^{b}$ \\ ${ }^{a}$ Chhattisgarh Council of Science \& Technology and ${ }^{b}$ School of Studies in Chemistry, \\ Pt. Ravishankar Shukla University Raipur (Chhattisgarh) - 492010, India
}

\begin{abstract}
Um método espectrofotométrico novo e altamente sensível foi desenvolvido para a determinação do inseticida cipermetrina em níveis de partes por milhão. O método é baseado na hidrólise alcalina de cipermetrina ao íon cianeto, o qual reage posteriormente com iodeto de potássio e leuco cristal violeta. A absorção máxima do corante cristal violeta formado é medida em $595 \mathrm{~nm}$ em meio ácido. A lei de Beer é obedecida no intervalo de concentração de 3,0 a $17 \mu \mathrm{g}$, em um volume final da solução de $25 \mathrm{~mL}(0,12-0,68 \mathrm{ppm})$. A absortividade molar e sensibilidade de Sandell encontradas foram $3,3 \times 10^{5} \mathrm{~L} \mathrm{~mol}^{-1} \mathrm{~cm}^{-1}$ e $0,054 \mu \mathrm{g} \mathrm{cm}^{-2}$, respectivamente. O desvio padrão e desvio padrão relativo foram $\pm 0,001$ e $0,22 \%$, respectivamente. O método é simples, sensível e livre de interferências de outros pesticidas e íons. Outros inseticidas piretróides não interferem no método proposto. O método tem sido aplicado satisfatoriamente para a determinação de cipermetrina em amostras ambientais e biológicas.
\end{abstract}

A new and highly sensitive spectrophotometric method was developed for the determination of parts per million levels of widely used cypermethrin insecticide. The method is based on alkaline hydrolysis of cypermethrin to cyanide ion, which further reacts with potassium iodide and leuco crystal violet. The absorption maxima of the crystal violet dye formed was measured at $595 \mathrm{~nm}$ in acidic medium. Beer's law obeys over the concentration range of 3.0 to $17 \mu \mathrm{g}$ in a final solution volume of $25 \mathrm{~mL}(0.12-0.68 \mathrm{ppm})$. The molar absorptivity and Sandell's sensitivity were found to be $3.3 \times 10^{5} \mathrm{~L} \mathrm{~mol}^{-1} \mathrm{~cm}^{-1}$ and $0.054 \mu \mathrm{g} \mathrm{cm}^{-2}$, respectively. The standard deviation and relative standard deviation were found to be \pm 0.001 and $0.22 \%$, respectively. The method is simple, sensitive and free from interferences of other pesticides and diverse ions. Other pyrethroid insecticides do not interfere in the proposed method. The method has been satisfactorily applied to the determination of cypermethrin in environmental and biological samples.

Keywords: spectrophotometry, cypermethrin, environmental, biological samples

\section{Introduction}

Pyrethroid insecticides are used to control a number of insect species on economic crops. Pyrethroid are effective pest control chemicals and have low mammalian toxicity. The pyrethroid insecticides containing a nitrile groop, viz. Cypermethin have been identified as highly effective contact insecticides. Owing to its availability, insecticides are misused in homicidal/suicidal poisoning cases. Consequently, detection and determination of these insecticides is necessary in forensic toxicology. ${ }^{1-6}$

*e-mail: ek_j13@rediff.mail.com
Cypermethrin (Ambush, Atroban, Biothrin) or (RS)cyano-3-phenoxybenzyl(1RS, 3RS; 1RS, 3RS)-(2,2dichloro-vinyl)-2,2-dimethylcyclopropanecarboxylate (IUPAC name cyano-(3-phenoxyphenyl)methyl] 3-(2,2dichloroethenyl)-2,2-dimethyl-cyclopropane-1carboxylate) is a digestive and contact insecticide effective against a wide range of pests, particularly leaf- and fruiteating Lepidoptera and Coleoptera in cotton, fruit, vegetables, vines, tobacco and other crops. Cypermethrin is widely used by farmers to control insect pests of vegetables. The acute oral $\mathrm{LD}_{50}$ for rats proposed for cypermethrin is $251 \mathrm{mg} \mathrm{kg}^{-1}$. 7, 8

Several modern instrumental techniques such as LC-MSMS, ${ }^{9}$ GC-MS, ${ }^{10}$ GC-ECD ${ }^{11}$ and a large number of 
chromatographic methods have been reported for residue analyses of synthetic pyrethroids. In autoradiographic thin layer chromatography (TLC), using ${ }^{14} \mathrm{C}$ labeled compounds, particularly in metabolic studies where the unlabelled compounds were detected by visualization on silica gel 60 $\mathrm{F}_{254}$ chromatographic plates under ultraviolet (UV) light, ${ }^{12-14}$ chromogenic reagents have been reported. For example, phosphomolybdic acid, ${ }^{15}$ palladium chloride, ${ }^{16}$ silver nitrate ${ }^{17}$ and copper(II) acetate, ${ }^{6}$ are selective for pyrethroid insecticides containing a nitrile group. Other analytical methods have been reported, like spectrophotometric and thermoanalytical study ${ }^{18}$ and spectrophotometric method with MBTH $^{19}$ (3-methyl-2-benzothiazolinone hydrochloride).

The aim of the present work is to develop a rapid, low cost, accurate and simple analytical method for the determination of cypermethrin at trace levels. In this paper, a simple and sensitive spectrophotometric method is described for the determination of cypermethrin, where cypermethrin is hydrolysed to give cyanide ion, which further reacts with potassium iodide and leuco crystal violet to produce a crystal violet dye with maximum absorbance at $595 \mathrm{~nm}$ in acidic medium. The reagent is selective for cypermethrin, amongst the pyrethroid group. The colour system obeys Beer's law in the range of 0.12-0.68 ppm of cypermethrin. The method has been applied to the determination of cypermethrin in various samples of water, vegetables, fruits, foliages and biological samples.

\section{Experimental}

\section{Apparatus}

A Systronics UV-Vis spectrophotometric model 104 with matched silica cells was used for all spectral measurements. A Systronic $\mathrm{pH}$ meter model 335 was used for $\mathrm{pH}$ measurements. A Remi C-854/4 clinical centrifuge force of $1850 \mathrm{~g}$ with fixed swing out rotors was used for centrifugation.

\section{Reagents}

All reagents used were of Anala $\mathrm{R}$ grade or of the best available quality. Double distilled demineralized water was used throughout. Cypermethrin (Syngenta Crop Protection Private Limited, India): A stock solution of 1 $\mathrm{mg} \mathrm{mL}^{-1}$ was prepared in ethanol. Working standard solutions were prepared by appropriate dilution of the stock standard solution with water. A 3\% hydrochloric acid aqueous solution was used. A $20 \%$ sodium hydroxide aqueous solution was used. ${ }^{6}$ A $0.1 \%$ potassium iodide aqueous solution was used. Leuco crystal violet (Eastman
Kodak Co.) [LCV] was prepared adding to a 1 liter volumetric flask $200 \mathrm{~mL}$ of water, $3 \mathrm{~mL}$ of $85 \%$ phosphoric acid and $250 \mathrm{mg}$ of leuco crystal, (4,4',4"'methylidynetris $\left(N, N^{\prime}\right.$,-dimethylaniline) $\left(\mathrm{CH}\left[\mathrm{C}_{6} \mathrm{H}_{4} \mathrm{~N}\right.\right.$ $\left.\left.\left(\mathrm{CH}_{3}\right)_{2}\right]_{3}\right)$. It was shaken gently until the dye gets dissolved. The content of the flask was then diluted to 1 liter with water. $^{20}$

\section{General procedure: preparation of calibration curve}

An aliquot of test solution containing 3.0 to $17 \mu \mathrm{g}$ of cypermethrin was taken in a $25 \mathrm{~mL}$ graduated cylinder and to it $1.0 \mathrm{~mL}$ of $20 \%$ sodium hydroxide was added. The solution was kept for $10 \mathrm{~min}$ at room temperature for complete hydrolysis. Then, $1 \mathrm{~mL}$ of $0.1 \%$ potassium iodide was added in acidic medium to liberate iodine and then 1 $\mathrm{mL}$ leuco crystal violet was added and shaken thoroughly and kept for $15 \mathrm{~min}$ for full colour development. The crystal violet dye was produced. The solution was then diluted to the mark with water and absorbance was measured at 595 $\mathrm{nm}$ against a reagent blank.

\section{Results and Discussion}

\section{Spectral characteristics}

The crystal violet dye formed in the proposed reaction shows maximum absorption at $595 \mathrm{~nm}$ (Figure 1). All spectral measurements were carried out against demineralized water as the reagent blank which showed negligible absorption at this wavelength. The colour system obeys Beer's law in the range of 3.0 to $17 \mu \mathrm{g}$ of cypermethrin per $25 \mathrm{~mL}$ of final solution at $595 \mathrm{~nm}$ (Figure 2). The molar absorptivity and Sandell's sensitivity were found to be $3.3 \times 10^{5} \mathrm{~L} \mathrm{~mol}^{-1} \mathrm{~cm}^{-1}$ and $0.054 \mu \mathrm{g} \mathrm{cm}^{-2}$, respectively.

\section{Optimization of conditions}

Hydrolysis of cypermethrin to cyanide ion was studied at different temperatures and alkalinity. It was observed that

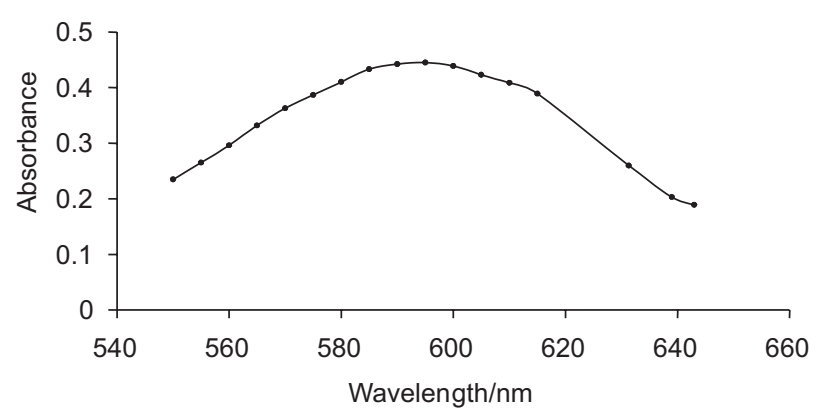

Figure 1. Absorption spectra of the dye formed by reaction of cypermethrin and leuco crystal violet. 


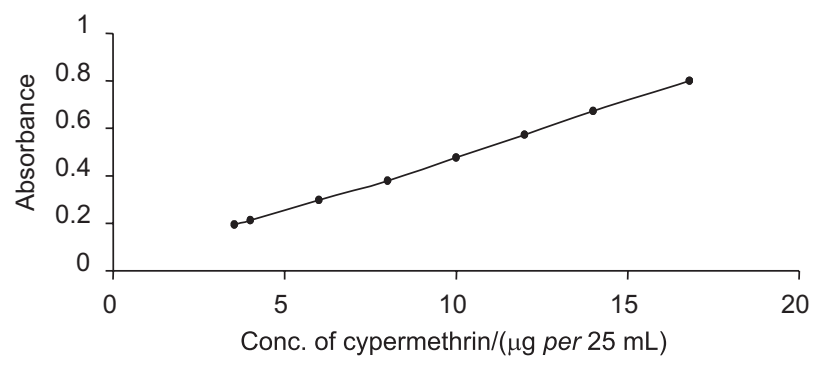

Figure 2. Beer's law of cypermethrin reaction product with leuco crystal violet.

alkaline conditions were required for the hydrolysis (Figure 3). Maximum hydrolysis ${ }^{6}$ was observed with $20 \%$ sodium hydroxide at temperature range of $30-35^{\circ} \mathrm{C}$ as it gave maximum absorbance values, good stability and quantitative results. It was observed that $1 \mathrm{~mL}$ of leuco crystal violet was sufficient for complete colour reaction (Figure 4).

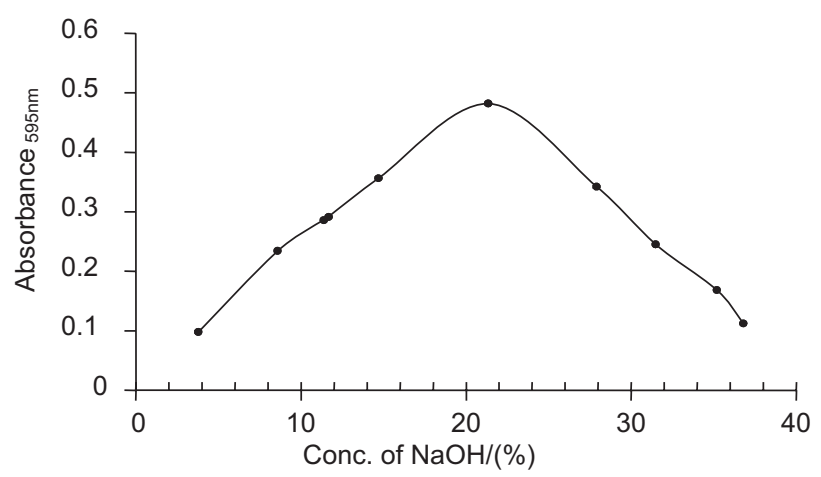

Figure 3. Concentration effect of $\mathrm{NaOH}$ on hydrolysis of cypermethrin to cyanide ion.

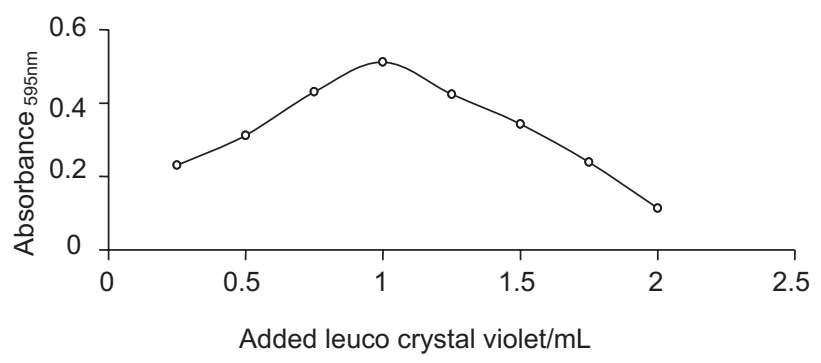

Figure 4. Concentration effect of Leuco crystal violet (solution prepared adding to a 1 liter volumetric flask $200 \mathrm{~mL}$ of water, $3 \mathrm{~mL}$ of $85 \%$ phosphoric acid and $250 \mathrm{mg}$ of leuco crystal, (4,4',4"'-methylidynetris $\left(N, N^{\prime}\right.$,dimethylaniline) $\left(\mathrm{CH}\left[\mathrm{C}_{6} \mathrm{H}_{4} \mathrm{~N}\left(\mathrm{CH}_{3}\right)_{2}\right]_{3}\right)$.

Table 1. Effect of foreign species for cypermethrin (10 ppm)
The effect of $\mathrm{pH}$ on the colour reaction was studied and it was found that constant absorbance values were obtained at $\mathrm{pH}$ range of $\sim$ 4.5-5.5 by hydrochloric acid and no buffer solution was required to stabilize the colour. The coloured species remain stable for more then 7 days under optimum conditions.

Precision of the method was checked by the replicate analysis of working standard solution containing $4 \mu \mathrm{g}$ of cypermethrin in $25 \mathrm{~mL}$ final solution over a period of 7 days. The standard deviation and relative standard deviation were found to be \pm 0.001 and $0.22 \%$ respectively.

\section{Effect of foreign species}

The effect of common foreign species and pesticides were studied to assess the validity of the method. Known amounts of foreign species and pesticides were added to the standard solution contained $10 \mu \mathrm{g}$ of cypermethrin prior to hydrolysis and the solution was analysed by the proposed method.The method was found to be free from interferences of most of the foreign species and pesticides (Table 1).

\section{Application}

Determination of cypermethrin in vegetables, fruits and foliages

Various samples of vegetables, fruits and foliages each of $25 \mathrm{mg}$, were taken, collected from agricultural fields, where cypermethrin had been sprayed as an insecticide. The samples were macerated with two $20 \mathrm{~mL}$ portions of ethanol-demineralized water $(1+1)$, filtered through a thin cotton cloth and filtrate was centrifuged at $1850 \mathrm{~g}$ for 10 min. In case of vegetables and fruits the filtrate was quantitatively transferred into a $50 \mathrm{~mL}$ volumetric flask and made up to the mark with $50 \%$ ethanol. Aliquots of supernatant were taken in a $25 \mathrm{~mL}$ graduated cylinder and then $1.0 \mathrm{~mL}$ of $20 \%$ sodium hydroxide was added and kept for $10 \mathrm{~min}$ at room temperature for complete hydrolysis. Then $1 \mathrm{~mL}$ of potassium iodide and leuco crystal violet was added in acidic medium and shaken thoroughly and kept for 15 min for full colour development. The solution

\begin{tabular}{lcc}
\hline Foreign species & $\begin{array}{c}\text { Tolerance limit } \\
\mu \mathrm{g} \text { in } 25 \mathrm{~mL}\end{array}$ & $\begin{array}{c}\text { Foreign species } \\
\mu \mathrm{g} \mathrm{in} 25 \mathrm{~mL}\end{array}$ \\
\hline Benzene & 5000 & $\mathrm{Al}^{3+}, \mathrm{Mg}^{2+}, \mathrm{Co}^{2+}$ \\
Phenol, Ethanol & 2500 & $\mathrm{Zn}^{2+}, \mathrm{Cu}^{2+}, \mathrm{Mn}^{2+}$ \\
Benzaldehyde & 2100 & $\mathrm{Fe}^{3+} \mathrm{Fe}^{2+}, \mathrm{Sb}^{3+}$ \\
Toluene, Xylene & 1500 & $\mathrm{Ni}^{2+}, \mathrm{Pb}^{2+}, \mathrm{Ca}^{2+}$ \\
Aniline, Formaldehyde & 900 & $\mathrm{Br}^{-}, \mathrm{CO}_{3}^{2-}, \mathrm{Cl}^{-}$ \\
Parathion, Malathion, Cresol & 500 & $\mathrm{NO}_{2}^{-}$ \\
Fenvalerate, Deltamethrin & $2^{\mathrm{b}}$ & 7300 \\
\hline
\end{tabular}

The amount causing an error of $\pm 2 \%$ in absorbance value. ${ }^{\mathrm{b}}$ Tolerance limit without its removal from the sample. 
was then diluted to the mark with water and absorbance was measured at $595 \mathrm{~nm}$ against a reagent blank.

In case of foliages, the filtrate was passed through a silica gel column $(10 \times 1 \mathrm{~cm})$ filled with $5 \mathrm{mg}$ silica gel, ${ }^{21}$ which was found to be sufficient for removal of chlorophyll and other interfering materials present in the extracted sample. The column was washed with $10 \mathrm{~mL}$ of $50 \%$ ethanol, washings were collected in a $25 \mathrm{~mL}$ volumetric flask and aliquots were analysed as recommended above (Table 2).

\section{Determination of cypermethrin in water}

River water samples, which received run off water from agricultural field, were collected. These samples were filtered through a Whatman No. 40 filter paper. Aliquots of water samples were taken in a $25 \mathrm{~mL}$ graduated cylinder, to it sodium hydroxide was added and analysed as described above (Table 2).

\section{Recovery of cypermethrin in biological samples}

The presence of cypermethrin in blood and urine has been reported in detectable concentration. ${ }^{22,23}$ Thus the method has been applied for the determination of cypermethrin in biological samples. Synthetic samples were prepared by adding known amounts of cypermethrin to these samples and than analysed after deproteination with trichloroacetic acid ${ }^{24,25}$ as described above (Table 3).

\section{Conclusions}

The proposed method is rapid, simple and sensitive and the reagent described here is sensitive and selective for cypermethrin insecticides containing a nitrile group. The lower limit of detection of the method is about $0.003 \mu \mathrm{g}$.

The proposed method has been applied to the determination of cypermethrin in various samples of water, vegetables, fruits, foliages and biological samples.

To check the recoveries, known amount of cypermethrin were added to various samples of vegetables, fruits, foliages and biological samples and then analysed by the proposed method (Tables 2 and 3).

\section{Acknowledgments}

Authors are thankful to the Head School of Studies in Chemistry Pt. Ravishankar Shukla University and Director General Chhattisgarh Council of Science \& Technology for providing laboratory facilities and financial assistance. One of them V. K. Gupta is thankful to A.I.C.T.E., New Delhi for Emeritus Fellowship.

Table 2. Determination of cypermethrin in environmental and agricultural samples

\begin{tabular}{|c|c|c|c|c|c|}
\hline Samples & $\begin{array}{l}\text { Cypermethrin } \\
\text { originally found } \mathrm{d}^{\mathrm{a}} \\
(\mu \mathrm{g}) \mathrm{x}\end{array}$ & $\begin{array}{c}\text { Cypermethrin } \\
\text { Added/( } \mu \mathrm{g}) \\
\mathrm{y}\end{array}$ & $\begin{array}{c}\text { Total } \\
\text { Cypermethrin } \\
\text { Found } /(\mu \mathrm{g}) \mathrm{z}\end{array}$ & $\begin{array}{l}\text { Difference/( } \mu \mathrm{g}) \\
\mathrm{z-X}\end{array}$ & $\begin{array}{c}\text { Recovery/(\%) } \\
(z-x) \times 100 / y\end{array}$ \\
\hline \multirow[t]{2}{*}{ Water ${ }^{b}$} & 1.36 & 5.0 & 6.31 & 4.95 & 99 \\
\hline & 4.56 & 15.0 & 19.13 & 14.57 & 97 \\
\hline \multirow[t]{2}{*}{ Tomato $^{c}$} & 2.03 & 5.0 & 6.84 & 4.81 & 96 \\
\hline & 4.81 & 15.0 & 19.36 & 14.55 & 97 \\
\hline \multirow[t]{2}{*}{ Apple $^{c}$} & 1.03 & 5.0 & 5.88 & 4.85 & 97 \\
\hline & 3.24 & 15.0 & 17.67 & 14.43 & 96 \\
\hline \multirow[t]{2}{*}{ Cauliflower $^{\mathrm{c}}$} & 3.42 & 5.0 & 7.56 & 4.14 & 83 \\
\hline & 5.35 & 15.0 & 19.65 & 14.3 & 95 \\
\hline \multirow[t]{2}{*}{ Cotton foliages ${ }^{c}$} & 2.96 & 5.0 & 7.86 & 4.90 & 98 \\
\hline & 4.56 & 15.0 & 18.96 & 14.4 & 96 \\
\hline
\end{tabular}

${ }^{\mathrm{a}}$ Mean of three replicate analyses; ${ }^{\mathrm{b}}$ Water sample $25 \mathrm{~mL}, 1 \mathrm{~mL}$ aliquot of sample was analyzed, after treatment as described in procedure; ${ }^{\mathrm{c}}$ Sample $25 \mathrm{~g}$ (sample taken from a field where cypermethrin had been sprayed).

Table 3. Recovery of cypermethrin in biological samples

\begin{tabular}{|c|c|c|c|c|}
\hline Samples & & Amount added $/(\mu \mathrm{g})$ & Amount found ${ }^{\mathrm{a}} /(\mu \mathrm{g})$ & Recovery/(\%) \\
\hline \multirow{2}{*}{ Blood $^{b}$} & $\mathrm{~A}$ & 4.0 & 3.69 & 92 \\
\hline & $\mathrm{B}$ & 8.0 & 7.76 & 97 \\
\hline \multirow{2}{*}{ Urine $^{\mathrm{b}}$} & A & 4.0 & 3.89 & 97 \\
\hline & $\mathrm{B}$ & 8.0 & 7.81 & 98 \\
\hline \multirow{2}{*}{ Cystein $^{\mathrm{b}}$} & $\mathrm{A}$ & 4.0 & 3.92 & 98 \\
\hline & $\mathrm{B}$ & 8.0 & 7.86 & 98 \\
\hline
\end{tabular}

${ }^{\mathrm{a}}$ Mean of three replicate analyses. ${ }^{\mathrm{b}}$ Amount of biological sample $=1 \mathrm{~mL}$. 


\section{References}

1. Pesticide Residues in Food 1981, Report of the Joint Meeting of the FAO Panel of Experts on Pesticide Residues in Food and the Environment and the WHO Expert Group on Pesticide Residues, FAO Plant Production and Protection Paper, No. 37, FAO, Rome, 1982.

2. Fine, B. C.; Pyrethrum Post 1963, 7, 18.

3. Farnham, A. W.; Pestic. Sci. 1973, 4, 513.

4. Elliott, M.; Janes, N. F.; Potter, C.; Annu. Rev. Entomol. 1978, $23,443$.

5. Elliott, M.; Pestic. Sci. 1980, 11, 119.

6. Vitthal, B. P.; Murlidhar, T. S.; Sudhakar, V. P.; Analyst 1992, 117, 75 .

7. Abdullah, M.; Sarnthoy, O.; Jiwajinda, S.; Kasetsart J. (Nat. Sci.) 2001, 35, 115

8. Ding, Y.; Catherine, A. W.; Muralidhara, S.; James, V. B.; Michael, G. B.; J. Chromatogr., B 2004, 810, 221.

9. Bauerle, G. F.; Ray, K. L.; Brodbelt, J. S.; Anal. Chem. Acta 1995, 317, 137.

10. Ramesh, A.; Ravi, P. E.; J. Chromatogr., B 2004, 802, 371.

11. Esteve-Turrillas, F. A.; Aman, C. S.; Pastor, A.; de la Guardia, M.; Anal. Chem. Acta 2004, 522, 73.

12. Roberts, T. R.; Standen, M. E.; Pestic. Sci. 1977, 8, 305.

13. Ruzo, L. O.; Holmstead, R. L.; Casida, J. E.; J. Agric. Food Chem. 1977, 25, 1385.
14. Gaughan, L. C.; Ackerman, M. E.; Unai, T.; Casida, J. E.; J. Agric. Food Chem. 1978, 26, 613.

15. Shono, T.; Ohsawa, K.; Casida, J. E., J. Agric. Food Chem. 1979, 27, 316.

16. Ruzo, L. O.; Engel, J. E.; Casida, J. E.; J. Agric. Food Chem. 1979, 27, 725 .

17. Sundararajan, R.; Chawla, R. P.; J. Assoc. Off. Anal. Chem. 1983, 66, 1009.

18. Orgoványi, J.; Otta, K. H.; Pöppl, L.; Fenyvesi, E.; Záray, G.; Microchem. J. 2005, 79, 77.

19. Kumar, K. S.; Swaroop, B. L.; Suvardhan, K.; Jayaraj, B.; Chiranjeevi, P.; Environ. Monit. Assess. 2007, 127, 1.

20. Agrawal, O.; Sunita, G.; Gupta, V. K.; J. Chin. Chem. Soc. 1999, 46, 641 .

21. Agrawal, V.; Gupta, V. K.; Fresenius J. Anal. Chem. 1993, 345, 720.

22. Upadhyay, S.; Gupta, V. K.; Analyst 1984, 109, 1619.

23. Raju, J.; Gupta, V. K.; Microchem. J. 1989, 39, 25.

24. Aldridge, W. N.; Analyst 1994, 69, 262.

25. Das, J.V.; Gupta, V. K.; Chem. Anal. 1994, 39, 693.

Received: June 20, 2006

Web Release Date: May 3, 2007 